\title{
Influence of Holding Time on Properties of Cemented Carbide- polycrystalline Diamond Compact Joints
}

\author{
Jia Qianzhong*, Li Man, Qu Fuzheng and Zhang Hongtao
}

School of Mechanical Engineering, Dalian University of Technology, Dalian, Liaoning, 116024, P. R. China

\begin{abstract}
The influence of brazing holding time on properties of cemented carbide-polycrystalline diamond (PCD) compact joints were investigated in this study. The microstructure and phase composition of joints were investigated by scanning electron microscopy, electron probe microanalyzer, and X-ray diffraction. Microstructural investigations revealed the presence of $\mathrm{Ag}$-based solid solution, $\mathrm{Cu}$-based solid solution, $\mathrm{Cu}_{0.64} \mathrm{Zn}_{0.36}$, and a small amount of MnNi phase at the joint interface. The max shear strength of brazed joints $350.6 \mathrm{MPa}$ was determined in the samples joined at $15 \mathrm{~s}$, which was partially due to the dispersion strengthening effect of gray-black grains containing $\mathrm{Cu}$-based solid solution, $\mathrm{Cu}_{0.64} \mathrm{Zn}_{0.36}$ and $\mathrm{MnNi}$ phase in the joints. Equal-area-circle grain diameter of the gray-black grains grew with longer holding time, whereas the shear strength decreased because of the formation of continuous intermetallic compounds layer along the joint boundary. Thermal damage of the PCD layer also deteriorated with increased holding time, and hence shorter holding time was preferable in the production.
\end{abstract}

Keywords: Brazed joint, holding time, polycrystalline diamond (PCD), shear strength, thermal damage.

\section{INTRODUCTION}

Polycrystalline diamond (PCD) compact is composed of PCD layer and carbide substrate [1]. PCD compact is applied in metal cutting processing and oil drilling industries because of the high hardness of PCD layer and good toughness of cemented carbide substrate [2-6]. PCD compact cutting tool is made of a PCD compact cutter head and a metal substrate. Brazing is a key procedure in the manufacturing of cutting tools. The reliability and integrity of PCD compact tools depend on the properties of PCD compact-metal joints during the brazing process.

Early research focused on the brazing of cemented carbide with dissimilar materials, such as A3 steel [7]. The brazing of PCD compact and cemented carbide is essentially a brazing process of cemented carbides. The brazing of cemented carbide is generally at about $1000{ }^{\circ} \mathrm{C}[7,8]$. However, the heat resistance of PCD layer is lower than 700 ${ }^{\circ} \mathrm{C}$, and thermal damage of PCD will happen when the temperature is too high [9]. Thus, the brazing of PCD compact usually uses Ag based brazing filler metal that has a relatively low melting point [10]. Hi-frequency induction brazing has been widely applied because of the properties such as easy operation, fast heating, high efficiency, less investment and lower operating cost. Studying the brazing parameters of PCD compact and making reasonable welding technology are significantly important for an increased edge quality. The present paper deals with the high-frequency induction brazing of PCD compact and YG8 cemented carbide based on $\mathrm{AgZnCuMnNi}$ filler metal.

*Address correspondence to this author at the School of Mechanical Engineering, Dalian University of Technology, Dalian, Liaoning, 116024, P.R. China; Tel\& Fax: +86 41184708815; E-mail: jiaqzh@163.com

1874-088X/15

\section{EXPERIMENT PROCEDURES}

PCD compact SynditeCTB010 (Element Six, British) and cemented carbide YG8 (Zhuzhou, China) were selected as welding materials for the brazing process. Table 1 shows the chemical compositions and melting temperature of filler metal. The thickness of AgZnCuMnNifoil was $0.1 \mathrm{~mm}$. QJ102 (Dahua, China), with activation temperature of 650$850{ }^{\circ} \mathrm{C}$, was chosen as brazing flux. The specimen size of PCD compact was $4 \mathrm{~mm} \times 2 \mathrm{~mm} \times 2 \mathrm{~mm}$, and YG8 has 8 $\mathrm{mm} \times 4 \mathrm{~mm} \times 2 \mathrm{~mm}$. Fig. (1) shows the connection form of the PCD compact and YG8.

Table 1. Chemical compositions and melting temperature of brazing filler metal.

\begin{tabular}{|c|c|c|c|c|c|}
\hline \multicolumn{4}{|c|}{ Chemical Compositions (wt\%) } & Melting Temperature $/{ }^{\circ} \mathrm{C}$ \\
\hline \hline $\mathrm{Ag}$ & $\mathrm{Zn}$ & $\mathrm{Cu}$ & $\mathrm{Mn}$ & $\mathrm{Ni}$ & $670-710$ \\
\hline 48 & 23 & 19 & 6.5 & 3.5 & \\
\hline
\end{tabular}

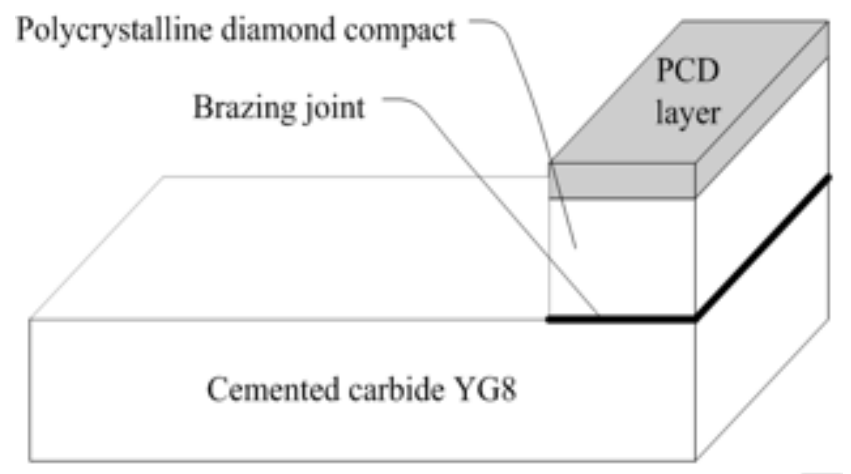

Fig. (1). Schematic of brazed joint. 
Prior to brazing, both substrates and brazing filler metal were polished with $\mathrm{SiC}$ papers, and subsequently cleaned using an ultrasonic bath with acetone as the fluid [11]. The brazing experiments occurred in high frequency induction heating equipment SP-15A (Shuangping, China). The brazing temperature was measured using an infrared radiation thermometer HSM-672 (Wahl, America).

In shear strength test, the average value in a set of three parallel specimens on the brazed specimen was examined using an Instron-1186 mechanical testing machine. Brazed joints were etched at room temperature for $15 \mathrm{~s}$ to observe the micro morphology. The etching solution was made up of $7 \% \mathrm{HCl}, 13 \% \mathrm{HNO}_{3}$ and $80 \% \mathrm{H}_{2} \mathrm{O}$. The interface structure of brazed joints and surface morphology of PCD layer were observed under a JSM-6360LV scanning electron microscope (SEM) (Shimadzu, Japan), which was equipped with an energy dispersive spectrometer. An electron probe microanalyzer (EPMA-1600) was used to analyze the distribution of elements in the brazed joints. The brazed joints were further observed through X-ray diffraction (XRD) experiments using an X-ray diffractometerXRD-6000 (Shimadzu, Japan).

\section{RESULTS AND DISCUSSION}

\subsection{Shear Strength}

Fig. (2) shows an overview of the shear strength of brazed joints under different holding times for samples brazed by $\mathrm{AgZnCuMnNi}$ filler metal at $690^{\circ} \mathrm{C}$. The changes of brazing holding time have great effects on the shear strength. When holding time was $15 \mathrm{~s}$, the shear strength of brazed joint reached a maximum of $350.6 \mathrm{MPa}$, which increased by about $30 \%$ than that with the holding time of 0 $\mathrm{s}$. The holding time of $15 \mathrm{~s}$ was long enough to ensure cemented carbide fully wetted by the filler metal, which guaranteed the discharge of oxide film and slag in the brazed joint, and promoted the spread process between the filler metal and the substrate. As the holding time extended to $30 \mathrm{~s}$, little change in shear strength occurred. However, the shear strength showed a downward trend when the holding

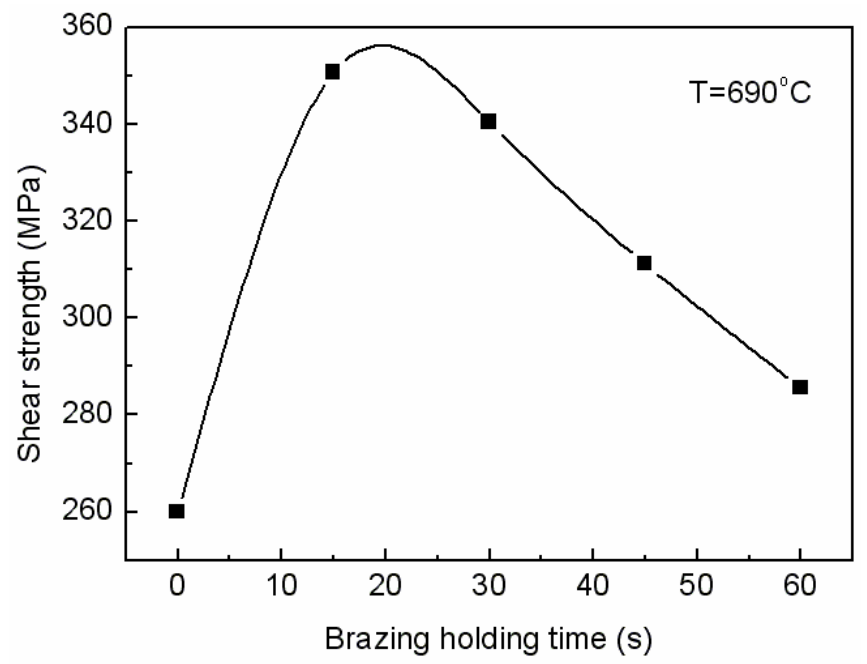

Fig. (2). Shear strength of the joints brazed at $690{ }^{\circ} \mathrm{C}$ under different holding times. time was prolonged to 45 and $60 \mathrm{~s}$. The downward trend may be caused by the missing and segregation of elements of the filler metal, because the brazed joint was exposed at high temperature for too long time. The segregation of elements in brazed joint will increase its brittleness and cause the joint strength to decline directly. Further observations on microstructure of brazed joint by SEM and EPMA are required in this study.

\subsection{Microstructural Investigation}

Fig. (3) presents overviews of the back scattered morphology of the brazed joint under different holding times at $690{ }^{\circ} \mathrm{C}$. The right is PCD compact, the left is YG8 cemented carbide substrate, and the middle is the filler alloy layer.

In the back scattered electron image, a dividing line is found between the filler metal alloy and cemented carbide. The tissue of brazed joint can be divided into two parts: the white zone with eutectic structure and the grey black zone with spotted structure. Table 2 lists the results of EPMA chemical analysis of the brazed joints in Fig. (3). The white zone was silver rich area and the grey black zone was zinccopper rich area. The binary phase diagram of $\mathrm{Ag} \mathrm{Cu}$ showed a eutectic reaction composed of $\mathrm{Ag} \mathrm{Cu}$ alloy at $779.1^{\circ} \mathrm{C}$ [12]. It can be seen in the diagram that the $\mathrm{Ag} \mathrm{Cu}$ eutectic temperature was reduced to about $675^{\circ} \mathrm{C}$ because of the addition of $\mathrm{Zn}$ from the $\mathrm{Ag}-\mathrm{Cu}-\mathrm{Zn}$ equivalent section phase diagram ( $\mathrm{Zn}$ content of 20\%) [13]. In this case, the white zone in Fig. (3) was mainly filled with Ag-based solid solutions and a small amount of acicular $\mathrm{Ag} \mathrm{Cu}$ eutectic. As shown in Table 2, the grey black zone contained $\mathrm{Ni}$ and $\mathrm{Cu}$. According to the phase diagrams, $\mathrm{Ag}, \mathrm{Cu}$, and $\mathrm{Ni}$ existed in face-centered cubic crystal lattices, and Mn existed as $\alpha-\mathrm{Mn}$ in body-centered cubic lattices below $727^{\circ} \mathrm{C}$. $\mathrm{Cu}-\mathrm{Ni}$ system is completely miscible, whereas, $\mathrm{Cu}-\mathrm{Mn}$ and $\mathrm{Ni}-\mathrm{Mn}$ systems are completely miscible at high temperature. Existing in close-packing hexagonal crystal lattices, the maximum solubility of $\mathrm{Zn}$ in $\mathrm{Ag}, \mathrm{Cu}$, and $\mathrm{Ni}$ reached $29 \%, 38 \%$, and $40 \%$ (mass fraction), respectively. Therefore, the grey black zone was mainly composed of $\mathrm{Cu}$-based solid solution and $\mathrm{Cu}-\mathrm{Zn}$ compound phase, and a small amount of $\mathrm{Mn}-\mathrm{Ni}$ compound phase. Previous study revealed that Ag-based solid solution has excellent strength and plastic property and $\mathrm{Cu}$-based solid solution has high strength phase [14]. In the present study, the grey black grains containing $\mathrm{Cu}$-based solid solution non-uniformly distributed in the brazed joint can make the brazed joint with good shear strength.

Fig. (3) showed that when the holding time was $15 \mathrm{~s}$ and $30 \mathrm{~s}$, the brazing filler metal had a good wetting with cemented carbide. Metallurgical bonding was obtained between the brazing filler metal and cemented carbide, and a thin layer and discontinuous transition layer along both the sides of the brazed joint generated. Gray black grains were non-uniformly distributed in the eutectic structure, which strengthened the brazed joints. However, with the prolonged holding time, the distribution of the grey black grains became sparser and the mutual fusion trend was inevitable in the brazed joints (Fig. 3c, d). When holding time was $15 \mathrm{~s}$, $30 \mathrm{~s}$, and $45 \mathrm{~s}$, the image analysis of the back-scattered electron images in Fig. (3) was performed using software 

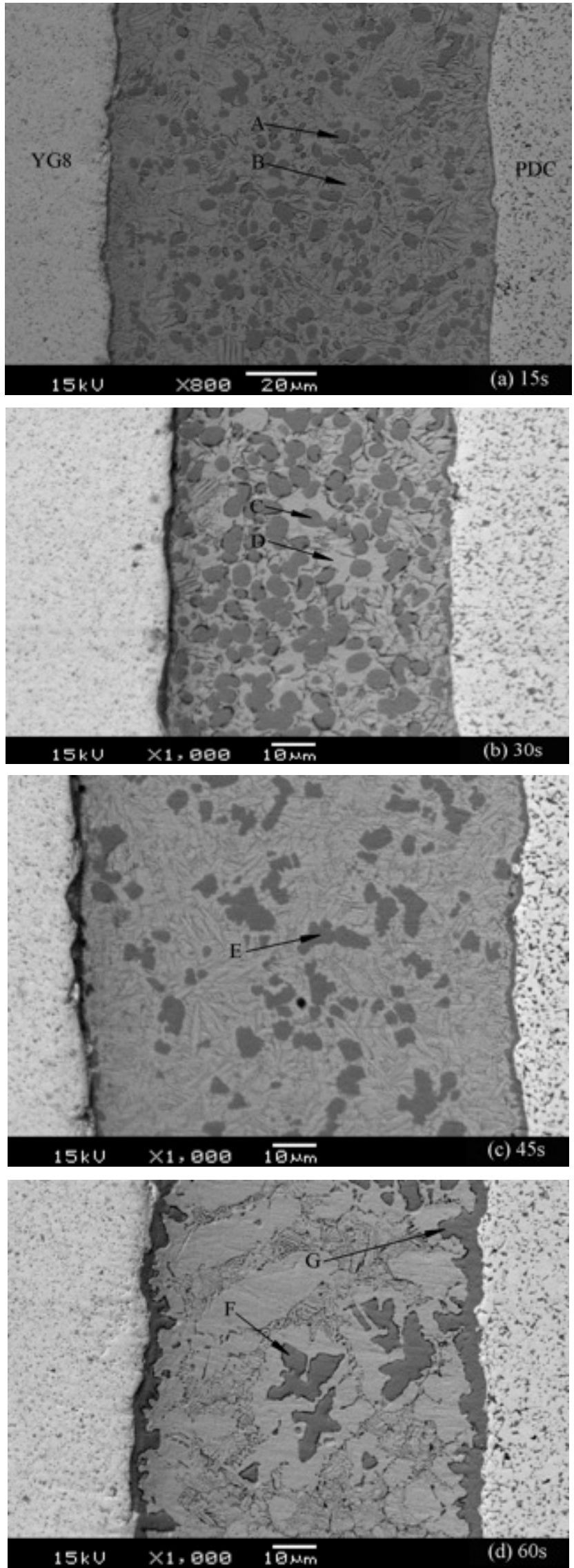

Fig. (3). Back-scattered electron image of the joints brazed at 690 ${ }^{\circ} \mathrm{C}$ under different holding times.
Image-Pro Plus (Table 3). The average equal-area-circle diameter of the gray black grains was $2.78 \mu \mathrm{m}$, and the average roundness was 0.77 when the brazing holding time was $15 \mathrm{~s}$. With increased brazing holding time, the average equal-area-circle diameter of the gray black grains gradually increased. However, the average roundness gradually decreased. Based on Hall-Petch law, smaller crystalline size means more grain boundaries, which has a greater hindering effect to external stress and larger shear strength of the brazed joint. Hence, the brazed joint with a holding time of $15 \mathrm{~s}$ had maximal shear strength in the test. As the holding time extended to $60 \mathrm{~s}$, the gray black grains in the brazed joints showed bulk reunion distribution and eutectic structures grains became coarse, which will directly influence the plastic property and toughness of the brazed joint. From Fig. (3d), the thickness increased on the grey black transitional zone on both sides of the brazed joint that reached up to about $5 \mu \mathrm{m}$. An intermetallic compound layer was generated because the compositions of the transition layer and the gray black grain were similar. However, continuous intermetallic compound layer has great brittleness, which leads to decreased shear strength of the brazed joint. The results were consistent with the obtained shear strength of the brazed joints.

To determine the reaction products and the element distribution of the brazed joints, X-ray diffraction analysis and quantitative elements surface scanning for the brazed joints were conducted (Figs. 4, 5). X-ray diffraction results showed that the main interfacial products were Ag-based solid solution, $\mathrm{Cu}$-based solid solution, $\mathrm{Cu}_{0.64} \mathrm{Zn}_{0.36}$, and $\mathrm{MnNi}$. The results were consistent with the previous analysis.

As shown in the EMPA (Fig. 5), the distribution of $\mathrm{Zn}$ in the brazed joint interface was relatively uniform and with no obvious gradient change. $\mathrm{Cu}$ mainly existed in the grey black zone, whereas Ag existed in few zones. $\mathrm{Mn}$ and Ni displayed minimal segregation on both sides of the brazed joint boundary besides the main distribution in the grey black zone. The distribution of $\mathrm{Mn}$ was also very similar to the distribution of $\mathrm{Ni}$, with the peaks of both elements appearing at the same position in the brazed joint. The similarity might be related to the structure of cemented carbide and the diffusion of elements during the formation process of brazed joint. Cemented carbide is essentially a kind of complex material which is made from discontinuous cobalt and tungsten carbide by random sintering process. Hence, numerous grain boundaries and voids exist in the cemented carbide. In the high-frequency induction brazing process, infiltration of the molten filler metal along the gaps of brazed joint under the influence of capillary action occurred first. Afterwards, the diffusions into the grain boundaries and voids of cemented carbide occurred. Filler metal infiltration is the main behavior at the start of the brazing process. With the holding time prolongation, element diffusion became more apparent. MnNi intermetallic compound formed and precipitated from the filler metal during the diffusion process. The $\mathrm{Cu}$-based solid solution crystallized relied on $\mathrm{MnNi}$ intermetallic compound as nucleus, which resulted in the segregation of $\mathrm{Mn}$ and $\mathrm{Ni}$ elements. When the holding time was longer enough, a continuous $\mathrm{MnNi}$ intermetallic layer formed in the boundary of brazed joint. The continuous formation led to less dispersion reinforcing phase, higher 
Table 2. Chemical compositions and distribution of microstructure zones in Fig. (3).

\begin{tabular}{|c|c|c|c|c|c|c|}
\hline \multirow{2}{*}{ Number } & \multirow{2}{*}{ Zone } & \multicolumn{5}{|c|}{ Elements and Contents (wt\%) } \\
\hline & & Ag & $\mathbf{Z n}$ & $\mathbf{C u}$ & Mn & $\mathbf{N i}$ \\
\hline \multirow{2}{*}{ Fig. (3a) } & A (black) & 3.16 & 45.96 & 30.15 & 11.49 & 9.24 \\
\hline & B (white) & 79.19 & 12.34 & 5.32 & 3.15 & \\
\hline \multirow{2}{*}{ Fig. (3b) } & C (black) & 3.08 & 47.75 & 29.73 & 10.30 & 9.14 \\
\hline & D (white) & 78.83 & 11.82 & 5.57 & 3.78 & \\
\hline Fig. (3c) & E (black) & 5.54 & 55.49 & 29.83 & 4.76 & 4.38 \\
\hline \multirow{2}{*}{ Fig. (3d) } & F (black) & 6.37 & 58.81 & 28.34 & 2.04 & 4.44 \\
\hline & G (black) & 6.53 & 50.78 & 32.21 & 5.57 & 4.91 \\
\hline
\end{tabular}

brittleness, and lower shear strength of the brazed joint. Hence, the distribution of grey black grains became sparser in the brazed joint. The results agreed with the results of shear strength of the brazed joint.

Table 3. Equal-area-circle grain diameter and roundness of gray-black grains in Fig. (3).

\begin{tabular}{|c|c|c|c|c|c|c|}
\hline \multirow{2}{*}{ Number } & \multicolumn{2}{|c|}{ Equal-Area-Circle Diameter/ $\boldsymbol{\mu m}$} & \multicolumn{3}{|c|}{ Roundness } \\
\cline { 2 - 7 } & Max & Mini & Average & Max & Mini & Average \\
\hline \hline Fig. (3a) & 6.36 & 0.6 & 2.78 & 1.32 & 0.35 & 0.77 \\
\hline Fig. (3b) & 7.2 & 0.86 & 3.61 & 1.11 & 0.3 & 0.74 \\
\hline Fig. (3c) & 9.67 & 0.39 & 3.71 & 1.29 & 0.24 & 0.51 \\
\hline
\end{tabular}

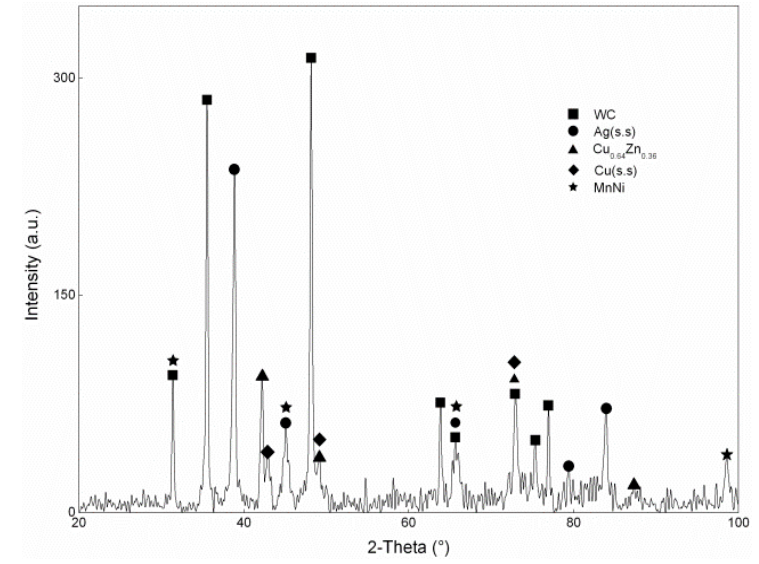

Fig. (4). XRD Pattern of brazed joint at $690{ }^{\circ} \mathrm{C}$ under holding time of $15 \mathrm{~s}$ fractured at PCD compact side.
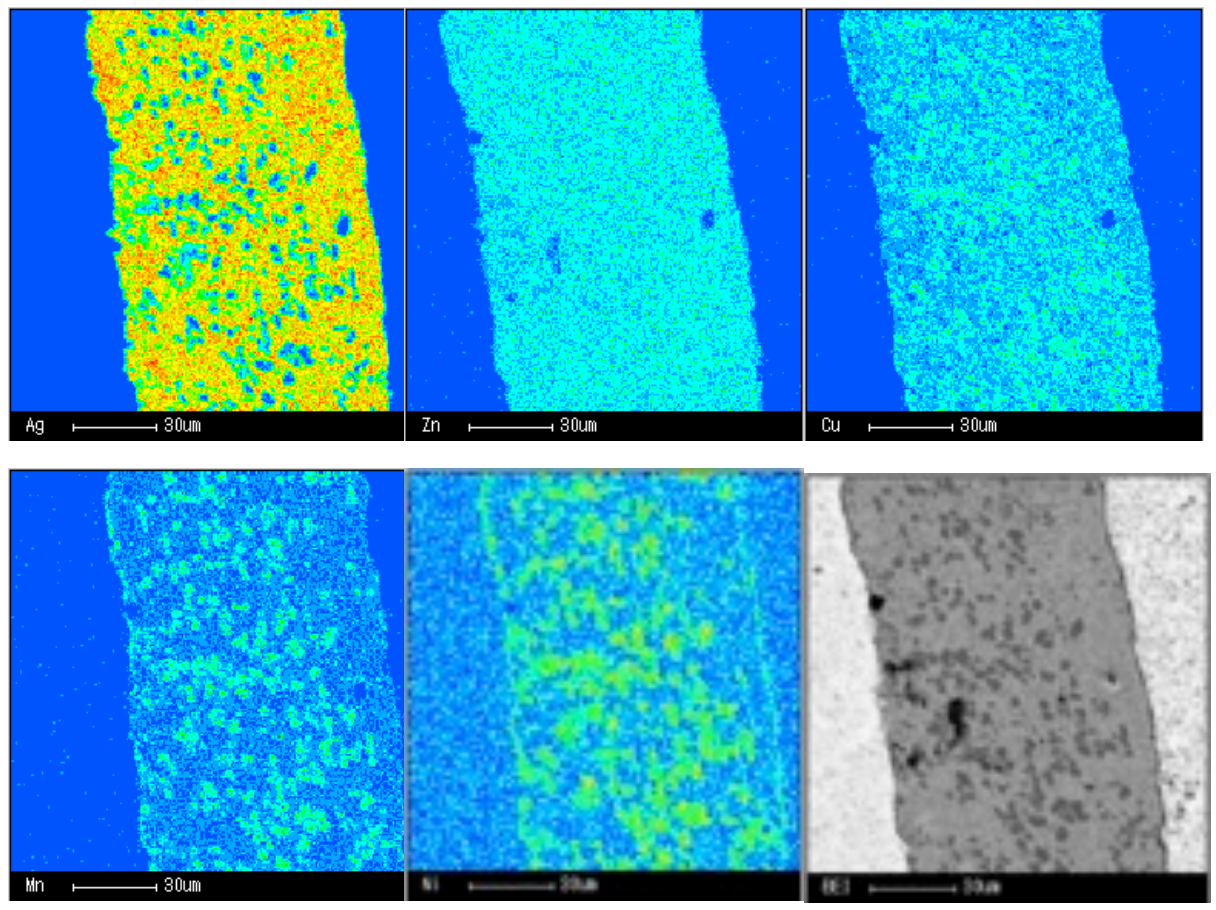

Fig. (5). EPMA mapping analysis of brazed joint at $690{ }^{\circ} \mathrm{C}$ under holding time of $15 \mathrm{~s}$. 


\section{THERMAL DAMAGE OF PCD LAYER}

Thermal damage of PCD refers to the damage caused by hearting during the brazing process [15]. In the present study, PCD surfaces under different holding times were all mirror surfaces at visual inspection. However, difference can be found when the PCD layers were observed by SEM. Fig. (6a) shows that the oxidation of white cobalt was not serious when the holding time was $15 \mathrm{~s}$. The cobalt was in the same plane with diamond crystals. With the prolongation of holding time (Fig. 6b, c), the cobalt and cobalt oxide evidently bulged on the diamond surface because of the surface tension effect. When the holding time was extended to $60 \mathrm{~s}$ (Fig. 6d), many pockmarks formed by the abscission of cobalt oxide appeared together with the white cobalt. Black spots and wrinkles also emerged on the diamond crystals because of oxidation. The PCD layer of CTB010 had grave thermal damage during high-frequency induction brazing, and even in a relatively low brazing temperature. Thermal damage will affect the smoothness of PCD layer and increase the friction coefficient of tool front face [16]. Service life of cutting tool will also decrease and the surface quality of machined work piece will be affected. Hence, brazing strength and shorter holding time are preferred in the high-frequency induction brazing process of PCD compact to ensure the performance of cutting tools.
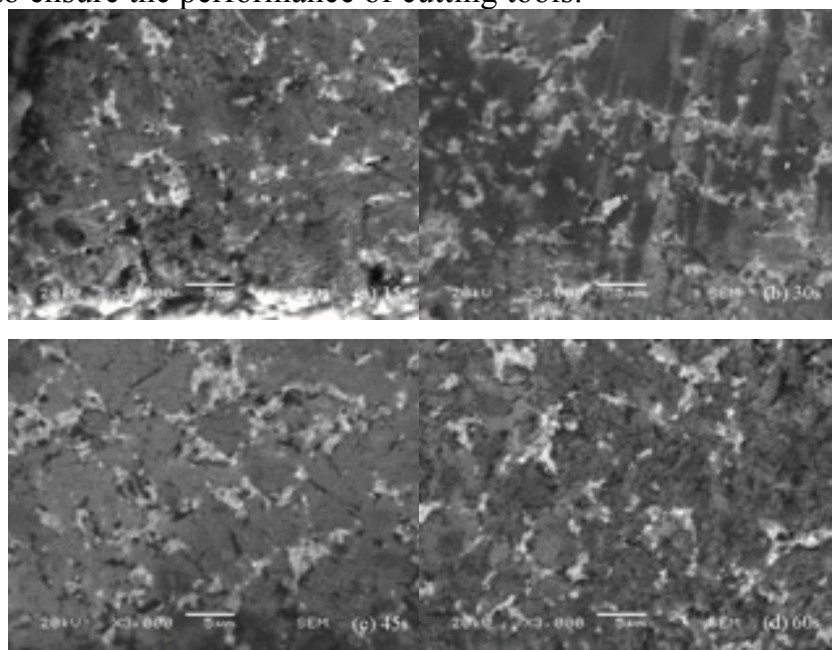

Fig. (6). Morphology of PCD brazed at $690{ }^{\circ} \mathrm{C}$ under different holding times.

\section{CONCLUSION}

High-frequency induction brazing of PCD compact CTB010 and YG8 cemented carbide was conducted using $\mathrm{AgZnCuMnNi}$ filler metal at $690{ }^{\circ} \mathrm{C}$. The shear strength of brazed joints increased at the early stage time but later decreased. When the holding time was $15 \mathrm{~s}$, the shear strength had a maximum value of $350.6 \mathrm{MPa}$.

The brazed joint was mainly composed of Ag-based solid solution, $\mathrm{Cu}$-based solid solution, $\mathrm{Cu}_{0.64} \mathrm{Zn}_{0.36}$ phase, and a little $\mathrm{MnNi}$ phase. Grey black grains containing $\mathrm{Cu}$-based solid solution, and $\mathrm{Cu}_{0.64} \mathrm{Zn}_{0.36}$ phase were non-uniformly distributed in Ag-based solid solution when the brazing holding time was $15 \mathrm{~s}$. The average equal-area-circle diameter of the gray black grains gradually enlarged with increased brazing holding time. The gray black grains of brazed joint showed bulk reunion distribution and a continuous $\mathrm{MnNi}$ intermetallic compound formed along the boundary of brazed joint as the holding time extended to $60 \mathrm{~s}$. As a result, the brazed joint became more brittle which was disadvantageous to joint strength.

With the prolongation of holding time, the cobalt and cobalt oxide evidently increased on the diamond surface. When the holding time extended to $60 \mathrm{~s}$, black spots and wrinkles appeared on the diamond crystals because of oxidation. As a result, the thermal damage of PCD layer became more serious.

\section{CONFLICT OF INTEREST}

The authors confirm that this article content has no conflict of interest.

\section{ACKNOWLEDGEMENTS}

Declared none.

\section{REFERENCES}

[1] Qian J, McMurray CE, Mukhopadhyay DK, Wiggins JK, Vail MA, Bertagnolli KE. Polycrystalline diamond cutters sintered with magnesium carbonate in cubic anvil press. Int $\mathbf{J}$ Refract Metals Hard Mat 2012; 31: 71-5.

[2] Gittel HJ. Cutting tool materials for high performance machining. Indust Diamond Rev 2001; 61: 17-21.

[3] Nabhani F. Wear mechanisms of ultra-hard cutting tools materials. J Mat Proces Technol 2001; 115: 402-12.

[4] Clark IE, Bex PA. The use of PCD for petroleum and mining drilling. Indust Diamond Rev 1999; 59: 43-9.

[5] Cook MW, Bossom PK. Trends and recent developments in the material manufacture and cutting tool application of polycrystalline diamond and polycrystalline cubic boron nitride. Int $\mathrm{J}$ Refract Metals Hard Mat 2000; 18: 147-52.

[6] Shalaby MA, El Hakim MA, Abdelhameed MM, Krzanowski JE, Veldhuis SC, Dosbaeva GK. Wear mechanisms of several cutting tool materials in hard turning of high carbon-chromium tool steel. Tribol Int 2014; 70: 148-54.

[7] Zhang J, Jin LY, Xu JC, Liu XQ. Microstructure and properties of brazing joint between YG8 cemented carbide and A3 steel. Design Interfac Struct Adv Mater Joints 2007; 127: 265-70.

[8] Uzkut M, Koksal NS, Unlu BS. The determination of element diffusion in connecting SAE 1040/WC material by brazing. J Mat Proces Technol 2005; 169: 409-13.

[9] Bex PA, Shafto GR. The influence of temperature and heating time on pcd performance. Indust Diamond Rev 1984; 44: 128-32.

[10] Zhang QY, Zhuang HS. Manual of brazing and soldering. Mechanical Industry Press, 2008, pp. 361-2.

[11] Echlin P, Handbook of sample preparation for scanning electron microscopy and x-ray microanalysis. Springer Verlag 2009, pp. 163-4.

[12] Tang RZ, Tian RZ. Binary alloy phase diagrams and crystal structure of intermediate phase. Central South University Press 2009; pp. 98-100.

[13] He CX. Phase diagrams of precious metal alloys and structure parameters of precious metal compounds. Metallurgical Industry Press 2007; pp. 448-9. 
[14] Songbai X, Yiyu Q, Xiaoping H, Zhenqing Z, Heming H. Behavior and influence of $\mathrm{Pb}$ and $\mathrm{Bi}$ in $\mathrm{Ag}-\mathrm{Cu}-\mathrm{Zn}$ brazing alloy. China Weld 2000; 9: 42-7.

[15] Shi W, Zhang H, Hai D. Grey relationship analysis and grey forecasting modeling on thermal stability of synthetic single diamond. J Harbin Instit Technol 2006; 13: 73-8.
[16] Slutz DE, Gigl PD, Flood GM, Smith GW. Brazed thermally-stable polycrystalline diamond compact work pieces and their fabrication. ed: EP Patent 0,329,954, 1993.

(C) Qianzhong et al.; Licensee Bentham Open.

This is an open access article licensed under the terms of the Creative Commons Attribution Non-Commercial License (http://creativecommons.org/licenses/ by-nc/4.0/) which permits unrestricted, non-commercial use, distribution and reproduction in any medium, provided the work is properly cited. 